\title{
DEVELOPMENT OF GRAMMATICAL ACTIVITIES IN A DIGITAL LEARNING ENVIRONMENT
}

\section{Samarina V., Shamrai O., Kharkiv National Automobile and Highway University}

\begin{abstract}
The article aims at highlighting the usefulness of grammatical explanations when associated with prototypes of actual productions of utterances. At the same time, textual functions of grammatical markers will be associated to complete the analysis of the textual structure.
\end{abstract}

Key words: discourse analysis, grammar, ICT, foreign language, cognition.

\section{Introduction}

The content of language teaching courses attested by university degrees does not always focus on the acquisition of skills that are useful primarily for communication. In this way, grammar can become in the eyes of learners an object of study in itself and for oneself, cut off from the purpose of communication, and in fact lose any raison to be in relation to the initial objective motivating the learning of a living language.

However, it is possible to envisage a grammar that is compatible with a project to acquire an L2 (and even more so a mother tongue) assessed on the basis of the competencies to be actively communicated in the target language. That is to say, a grammar that reflects the functioning of verbal interactions, a grammar of "discourse"1. In this functionalist perspective (in agreement with the CEFR, Council of Europe, 2001), and while taking into account cognitive data essential for learning L2, the object of this article will be to explore the possibilities offered by ICT (information and communication technologies in education) for a grammatical contribution anchored in the practices of the language in situation. It seems to us, in fact, that the ICT open up possibilities that are still underutilized both in terms of the description of language functioning and in terms of pedagogical activities and learning aids that they allow [1].

\section{Purpose and Problem Description}

Our descriptive and explanatory objective is to report on the functioning of the language. The aim is to propose "tools" that favor the production of texts anchored in authentic verbal interactions. The grammar resulting from this approach aims to reflect the reality of the cognitive and social functioning of the language and is not situated in a theoretical linguistic framework given a priori. It is therefore not a matter of de- riving or adapting a particular linguistic model. There are many of them whose internal functioning is coherent in itself, within the framework defined by their initial assumptions. Moreover, as it stands at present, there is no linguistic model that can account for all the enunciative and textual parameters underlying the actual use of the language.

\section{Analysis}

It should not be overlooked that "the ultimate test of grammatical knowledge, beyond the science of rules and mastery of forms, remains undeniably a communicative performance in tune with intentions of meaning and social codes of interaction" [2, p.64]. In short, simple common sense precludes plunging modern language students into the abundance of linguistic theories (and even less advanced learners in particular) with the unrealistic hope that their language practice in L2 will be reinforced by this bath in moving waters.

The classical grammar does not take into account the discursive context from which the statement is taken, nor does it take into account the communication situation for which it was conceived. Yet learners (adolescents and adults) resist, often unconsciously, this dissociation imposed by traditional reflective grammatical activity between the enunciator, his or her conditions of enunciation and reception, and the enunciation itself, simply because this dissociation is not habitual, "natural" [3, p.19].

Prototypes of verbal interaction situations in relation to the meanings assigned to grammatical tools should be included in the grammatical description. These situational prototypes, in close connection with the grammatical tools that constitute their marks or clues, play an essential role in recalling knowledge at the appropriate time of reuse. These prototypes incorporate systematically relevant elements from the communication situation. These elements concern in 
particular the interacting protagonists (and their social or personal relations), the nature of the communication channel, the overall aim of the speech act and the textual gender associated with it. At the same time, it is also necessary to clearly define how texts are drafted and to relate the functions of grammatical tools to their role as markers of textual parts.

\section{ICT and grammar: revision of teaching content and associated activities}

Before talking about the interest represented by the ICT, we must remind ourselves of the shortcomings that they can induce if we are not careful to subordinate the use of the medium to a project built on structured and solid scenarios on complementary levels such as linguistics (especially the grammatical aspect for us), cognition and, of course, didactics. "Any pedagogical situation implies a position on what learning and the object of study is. When you try to do something with the machine, you are usually very far from it "[ $[4, \mathrm{p} .12]$. The learner's objective is not to learn how to use software or other tools, but to learn a language: the use of the medium must be as transparent and manageable as possible. Lapaire [2, p.59] also stresses the need to effectively take advantage of the special qualities of ICT, which are different from those of paperbased ICT.

Clearly, simply transferring rules, examples or exercises such as "paper" to the screen is more a matter of gadgetisation than innovation. It will be easy to accept that a dematerialization that scans but does not reformat, that returns to the screen "paper" exercises without creating new ones, that does not exploit the "multi" dimension of multimedia (by integrating sound, animation of images, interactivity) is of little interest. Anyone who offers a study of grammar in a multimedia workshop must not only commit himself or herself to changing their practices, but must also agree to modify their understanding of grammar and the teaching of language facts.

Associating grammar with ICT means exploiting as many paths as possible opened up by digital environments thanks to multimodality, hypertextuality and interactivity, in particular. Interactions between users allow for all possible pairings: interlearners, tutors, pairs or groups.

\section{ICT and activity of reorganization of the grammatical acquis}

Weinrich's emphasis [5] is a textual distribution principle that opposes imperfectness on the one hand with the simple past (or the compound past) on the other. This explanatory principle states that the imperfect is used with what constitutes the background of the narrative (the setting, repetitive events, secondary circumstances, comments, details), while the salient events of the narrative plot, are associated with the compound past or the simple past. Unfortunately, many contexts resist in text production an explanation of the distribution of verbal times according to emphasis, because one can often reason in the sense of a categorization of trials in the foreground as well as another equally coherent argument in the background.

The textual information is hierarchized by the receiver according to a cognitive principle which consists in selecting and organizing certain information in the foreground on a background set back from it, according to the degree of subjective interest accorded to this or that element. It is very likely that this cognitive resonance of the emphasis principle explains the reasons for its didactic appeal. The cognitive distribution according to the first and background is the result of decoding a subjective categorization activity (related, among other factors, to the interests of the receiver), while the distribution of verbal forms is far from subjective: there are many contexts in which a single verbal form will be perceived as grammatical by a native, to the exclusion of others.

The more the learner reflects on a text (for example, to translate it), the more elusive the distribution between the first and the background appears to be. One can, of course, generally agree on the main ideas or events of a text, for example, to make a summary of it. But when working on the text in a "close-up" format, verb after verb - which is what a translation exercise requires, for example - it becomes impossible to categorize the various trials objectively and definitively according to the principles of emphasis. And so we have seen many theme courses for German-speaking students get lost in discussions without a final consensus among the participants. After reading the text and summarizing which functions are defined for imperfect and simple or compound past, the task proposed to the learners was twofold. It was first a question of defining, on the basis of the text, whether it was possible to define systematic employment rules for verbal times based on their (assumed) highlighting function. The learners could thus see for themselves that the wording suggests that there might be didactic difficulties; since the rules generalize employment contexts posed 
here as statistical frequencies. Once the essential features of emphasis have been established, the second exploratory stage of the grammatical heritage can be initiated. Learners can explore textbooks and sites (using links provided by the teacher or in open source research as part of an intermediate task) to collect rules from Weinrich's theory and the accompanying illustrative examples. The identification of the proposed rules must be attentive to the precise formulations they adopt: the evaluation of their predictive scope and therefore their didactic value depends, of course, on it. The development of this type of activity and the expected benefits can also be optimized by using ICT. The availability of a corpus of texts on a virtual desktop makes it possible to significantly increase the number of texts available to learners, which is necessarily more limited by the manipulation of paper documents. The role of the tutor is obviously to provide an appropriate corpus for targeted research, to initiate the use of the tools and software used, but also to help learners to formulate what types of contexts it may be interesting to update, based on the synthesis of rules previously compiled and the formulation of application difficulties they may have encountered personally. This confrontation of authentic texts with established grammatical beliefs helps to illustrate the limits of authentic texts (subject, of course, to the condition that "recalcitrant" texts are not removed from the corpus for the rules to be questioned).

Beyond the question of emphasis, an activity of confrontation of authentic texts with grammatical discourses generally allows learners to "understand for themselves the statistical reality of the phenomena studied". This observation - to which we add ourselves - is made by Lapaire [2] who conducts this type of activity in English as a foreign language, encouraging them by using the tools mentioned above. In conjunction with the important "awareness of the variety of grammatical polysemy", the benefits for learners are notable in terms of motivation: "From the very first sessions, we were able to observe a stronger motivation and a higher quality of concentration" $[2, \mathrm{p} .63]$. This increase in motivation is most likely based on an increase in selfconfidence, but also on confidence in the interest of "doing grammar" to promote the learning and use of the language.

\section{Conclusion}

In conclusion, we can recall first of all these didactic evidences: communicative performanc- es cannot be favoured by applicationist linguistic speculation, nor by a focus on the handling of ICT.

Exploring the potentialities offered by the ICT can only convince you of their interest in language teaching/learning (whether mother tongue or L2) for various complementary reasons.

The ICT (hypertext, among others, but also the exploitation of the visual dimension, cf. [6] promote the effective integration of enunciation and text into grammatical teaching content. They can also promote the acquisition of text comprehension routines (and correlatively verbal production routines) at all levels (sociolinguistic, pragmatic, lexical, grammatical, and phonetic).

The ICT massively broaden the range of pedagogical activities and allow for the development of refined tutorial practices $[7,8]$ with a view to empowering and empowering learners, leading their learning, but also with a view to developing the socio-affective aspects of learning. Various types of software or systems can be used to support the activities: podcasting [2], patches [9], distance learning platforms, concordanciers to facilitate the exploration of corpus of texts and of course forums. At the same time, research activities can also be equipped with instruments that facilitate it [10].

\section{References}

1. Demaizière F. Didactique des langues et TIC : les aides à l'apprentissage / Françoise Demaizière // Alsic [En ligne]. - Vol. 10, $\mathrm{n}^{\circ}$ 1. - 2007. document alsic_v10_01-rec1, mis en ligne le 30 mars 2007. Consulté le 23 avril 2018. - Режим доступу :

http://journals.openedition.org/alsic/220 ; DOI : $10.4000 /$ alsic. 220

2. Lapaire Jean-Rémi. De la grammaire anglaise baladodiffusée au portfolio grammatical électronique: vers de nouvelles pratiques adaptées à l'ère du numérique / Jean-Rémi Lapaire // Alsic [En ligne]. - Vol. 12. - 2009. mis en ligne le 06 décembre 2009. Consulté le 23 avril 2018. - Режим доступу : http://journals.openedition.org/alsic/1314; DOI : 10.4000/alsic. 1314

3. Besse, H. Grammaires et didactique des langues / H. Besse, R. Porquier. - Paris : Crédif-Hatier, 1991. $-286 \mathrm{p}$.

4. Barbazan M. Intégrer les Tice à une approche cognitive de la grammaire du discours / Muriel Barbazan // Alsic [En ligne]. - Vol. 14. - 2011. mis en ligne le 10 septembre 2011. Consulté le 23 avril 2018. - Режим доступу : http://journals.openedition.org/alsic/2337 ; DOI : 10.4000/alsic. 2337 
5. Weinrich H. Textgrammatik der französischen Sprache / H. Weinrich. - Stuttgart : Klett, 1982. $894 \mathrm{~S}$.

6. Lehuen, J. Simulation Globale en Réseau pour le FLE ? La Plate-forme Informatique MEPA-2D / J. Lehuen, S. Kitlinska // Sticef. - vol. 13. - 2006. - Режим доступу : http://sticef.univlemans.fr/num/vol2006/lehuen06/sticef_2006_lehuen_06p.pdf

7. Dejean-Thircuir $\mathrm{Ch}$. Modalités de collaboration entre étudiants et constitution d'une communauté dans une activité à distance / Charlotte DejeanThircuir // Alsic [En ligne]. -Vol. 11. - n¹. 2008. - document alsic_v11_07-rec2, mis en ligne le 30 juin 2008. Consulté le 23 avril 2018. Режим доступу : http://journals.openedition.org/alsic/803 ; DOI : 10.4000/alsic. 803

8. Mangenot F. Pratiques pédagogiques instrumentées et propriétés des outils : le cas des forums / François Mangenot // Revue STICEF. Volume 15. - 2008. - Режим доступу : http://sticef.org

\section{References}

1. Demaizière F. Didactique des langues et TIC : les aides à l'apprentissage // Alsic [En ligne]. - Vol. 10, $\mathrm{n}^{\circ}$ 1. - 2007. - document alsic_v10_01-rec1, mis en ligne le 30 mars 2007. Consulté le 23 avril 2018. Available at : http://journals.openedition.org/alsic/220 ; DOI : $10.4000 /$ alsic. 220

2. Lapaire Jean-Rémi. De la grammaire anglaise baladodiffusée au portfolio grammatical électronique: vers de nouvelles pratiques adaptées à l'ère du numérique // Alsic [En ligne]. - Vol. 12. - 2009. - mis en ligne le 06 décembre 2009. Consulté le 23 avril 2018. - Available at : http://journals.openedition.org/alsic/1314; DOI : 10.4000/alsic. 1314

3. Besse H., Porquier R. Grammaires et didactique des langues. - Paris: Crédif-Hatier, 1991. $286 \mathrm{p}$.

4. Barbazan Muriel. Intégrer les Tice à une approche cognitive de la grammaire du discours // Alsic [En ligne]. - Vol. 14. - 2011. - mis en ligne le 10 septembre 2011. Consulté le 23 avril 2018. - Available at :

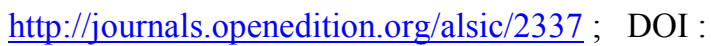
$10.4000 /$ alsic. 2337

5. Weinrich H. Textgrammatik der französischen Sprache. - Stuttgart : Klett, 1982. - 894 S.

6. Lehuen J., Kitlinska S. Simulation Globale en Réseau pour le FLE ? La Plate-forme Informatique MEPA-2D // Sticef. - vol. 13. 2006. - Available at: http://sticef.univlemans.fr/num/vol2006/lehuen06/sticef 2006 lehuen 06p.pdf

7. Dejean-Thircuir Charlotte. Modalités de collaboration entre étudiants et constitution d'une communauté dans une activité à distance // Alsic [En ligne]. -Vol. 11. - n 1. - 2008. - document alsic_v11_07-rec2, mis en ligne le 30 juin 2008. Consulté le 23 avril 2018. - Available at : http://journals.openedition.org/alsic/803 ; DOI : 10.4000/alsic. 803

8. Mangenot François. Pratiques pédagogiques instrumentées et propriétés des outils : le cas des forums // Revue STICEF. -Volume 15. - 2008. Available at : http://sticef.org

\section{Розвиток граматичної діяльності в цифровому середовищі навчання}

СамарінаВікторія Вікторівна, к.філол. н., доц., Шамрай Олена Василівна, ст. викл., Харківський національний автомобільнодорожній університет,

Харків, вул. Ярослава Мудрого, 25

+380502813894, samarinavictoria@ukr.net, +38095347849, shamrai.elena27@gmail.com

Анотація. Стаття спрямована на висвітлення корисності граматичних пояснень, пов'язаних із прототипами реальних постановок висловлювань. У світлі результатів психолінгвістики та когнітивної психології, щзо стосуються моделей навчання та усних виробничих прочесів, ия стаття має дві иүілі. Перш ніж досліджувати потенційний розвиток граматичної діяльності в середовищі иүифрового навчання, у першій частині вивчається, як ми можемо збагнути граматичні пояснення, спрямовані на інтеграцію поточних результатів з аналізу дискурсу та текстової лінгвістики. Ця перша частина спрямована на висвітлення корисності граматичних пояснень, коли це пов'язано з прототипами реальних постановок висловлювань. У той же час текстові функиії пов'язані граматичними маркерами для завершення аналізу текстової структури. У другій частині статті досліджуються можливості створення дидактичної діяльності з ресурсами IKT, які можуть допомогти учням усвідомити граматичні прочедури для відповідного виробництвва та прийому дискурсів у реальних ситуаціях. Ситуативні прототипи, в тісному зв'язку з граматичними інструментами, щуо складають їх ознаки або підказки, відіграють важливу роль у відновленні знань у відповідний час для повторного використання. Мета полягає в тому, щоб запропонувати «інструменти», які сприяють укладанню текстів, які закріплені за автентичними вербальними взаємодіями. Граматика, щяо $\epsilon$ результатом изього підходу, спрямована на відображення реальності когнітивного та соціального функціонування мови $i$ не входить $у$ теоретичну лінгвістичну структуру, визначену aпріорі. Отже, це не питання отримання або адаптації певної мовної моделі. Інформаційнокомунікаційні технології розщирюють спектр педагогічної діяльності та сприяють розвитку більш складних методів навчання, з метою розширення можслиостей учнів, щчо сприяє їх навчанню, а також із метою розвитку соиіально- 
емочійних аспектів навчання. Наявність корпусу текстів на віртуальному робочому столі дає змогу значно збільшити кількість текстів, доступних учням, щуо обов'язково обмежується при маніпулюванні паперовими документами. Роль куратора, очевидно, полягає в тому, щзоб забезпечити відповідний корпус для иілеспрямованих досліджень, ініціювати використання інструментів та програмного забезпечення, щзо вже використовувались, а також допомогти учням сформулювати, які типи контекстів можуть бути цікавими для корекції, на основі синтезу раніме сформованих правил та формулювання труднощчів, пов'язаних із їх застосуванням, які вони могли зустріти особисто.

Різні типи програмного забезпечення або систем можуть бути використані для підтримки діяльності: підкастінг, патчі, платформи дистаниійного навчання, форуми для полегшення вивчення корпусу текстів. У той же час науководослідна діяльність також може бути оснащена інструментами, які полегшують ї.
Ключові слова: аналіз дискурсу, граматика, ІКТ іноземна мова, пізнання.

\section{Развитие грамматической деятельности в цифровой среде обучения}

Виктория Викторовна Самарина, к.филол. н., доц.,

Елена Васильевна Шамрай, ст. препод., Харьковский национальный автомобильнодорожный университет, г. Харьков, +380502813894, samarinaviktoria@ukr.net, +38095347849, shamrai.elena27@gmail.com

Аннотация. Статья направлена на освещение полезности грамматических объяснений, связанных с прототипами реальных постановок высказываний. В то же время текстовые функции грамматических маркеров будут связаны с завершением анализа текстовой структуры.

Ключевые слова: анализ дискурса, граммати-

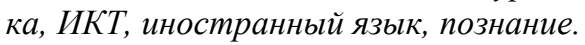

